\title{
A Role for Mineralocorticoid Receptors in the Physiology of the Ovine Fetus: Effects on ACTH and Lung Liquid Composition
}

\author{
MAUREEN KELLER-WOOD, CHARLES E. WOOD, JARRET MCCARTNEY, NATHAN M. JESSE, AND DANA PERRONE \\ Departments of Pharmacodynamics [M.K.-W., J.M., D.P.], Physiology and Functional Genomics [C.E.W.], and Pediatrics [N.M.J.] \\ University of Florida, Gainesville, Florida 32610
}

\begin{abstract}
In the human and ovine fetus, the presence of $11 \beta$ hydroxysteroid dehydrogenase 1 allows cortisol and other corticosteroids to act at mineralocorticoid receptors (MRs) in lung and brain. To test the physiologic role of MRs in the late gestation fetus, fetal lambs were infused with a specific MR antagonist for $12 \mathrm{~h}$. Infusion of the MR antagonist significantly increased plasma ACTH and cortisol concentrations. Infusion of the MR antagonist also significantly increased fetal $\mathrm{PCO}_{2}$ and hematocrit, and decreased fetal $\mathrm{pH}$, but did not alter fetal heart rate or blood pressure. Infusion of the MR antagonist altered the ratio of $\mathrm{Na}^{+}$to $\mathrm{K}^{+}$in lung fluid but did not alter the rate of production of lung liquid or the expression of the epithelial sodium channel $\alpha$ or of the Na,K ATPase $\alpha 1$ in lung. These results suggest that corticosteroids act at MR to regulate ACTH and blood volume and modulate lung fluid composition in the fetus, but basal levels of corticosteroids do not alter lung liquid production rate through effects on MR. (Pediatr Res 69: 491-496, 2011)
\end{abstract}

$\mathrm{C}$ orticosteroids exert important maturational and activational effects in fetal tissues at term, including influencing the maturation of the liver, lungs, pancreas, and gastrointestinal tract, and effects on the brain, adrenal medulla, and adrenal cortex (1). In the course of normal gestation, these effects are stimulated by the increase in fetal adrenal secretion of cortisol, which precedes delivery. These effects can be induced through glucocorticoid receptor (GR) activation by synthetic glucocorticoids (2-6).

Before the time of fetal adrenal maturation, fetal cortisol levels are appreciably lower and are derived primarily from transplacental passage of maternally produced cortisol $(7,8)$. These low plasma cortisol concentrations are within the range expected to cause greater occupancy and action via the mineralocorticoid receptor (MR) than GR (9). In humans and sheep, MR are expressed before birth (10-12) and in fetal lung, hypothalamus, and hippocampus, the reductase activity of 11 beta hydroxysteroid dehydrogenase $1(11 \beta \mathrm{HSD} 1)$ predominates over the cortisol-inactivating dehydrogenase activity of $11 \beta \mathrm{HSD} 2$ (13). Therefore, cortisol and the classical mineralocorticoids aldosterone and 11-deoxycortisol could bind to MR in the ovine fetal brain and lung and exert physiologic effects before the time of the periparturient surge in cortisol production by the fetal adrenal. We hypothesize

Received September 29, 2010; accepted December 29, 2010.

Correspondence: Maureen Keller-Wood, Ph.D., Department of Pharmacodynamics, University of Florida, Box 100487, Gainesville, FL 32610; e-mail: kellerwd@ cop.ufl.edu

Supported by a grant from the NIH DK062080 [M.K.-W.] and by a fellowship grant from the American Heart Association Florida-Southeast Affiliate [N.M.J.]. that low levels of corticosteroids do have effects in the fetus; in the late gestation, fetal heart MRs are involved in the enlargement produced by cortisol (14). These studies were designed to test the hypothesis that endogenous corticosteroids act at MR to regulate ACTH and lung liquid composition or production in the late gestation fetus at an age at which MR are abundantly expressed in both hypothalamus and lung $(10,11)$.

\section{METHODS}

Experimental protocol. These experiments were approved by the University of Florida IACUC. Ewes with singleton fetuses (113-122 d gestation) were prepared with catheters in the fetal tibial arteries, saphenous veins, amniotic space, and maternal femoral arteries and veins. For sampling of lung liquid, two nonocclusive catheters were placed in the fetal trachea, one advanced toward the lung and one toward the larynx $(15,16)$; these were joined to form a circuit to allow free flow of fluid before the lung liquid sampling period.

Ewes were treated with ampicillin (750 mg Polyflex; Fort Dodge, IA), and body temperature was monitored for $5 \mathrm{~d}$ postoperatively. Animals were subsequently studied during an 18-h period, ending on 120-132 d gestation $(126 \pm 2$; fetal body weight $2.96 \pm 0.17 \mathrm{~kg})$. Maternal and fetal blood samples for blood gases, plasma hormones, electrolytes, and osmolality were collected before the start of the fetal i.v. infusion of MR antagonist (RU26752; Sigma Chemical Co.-Aldrich, St. Louis, MO; $1.68 \mathrm{mg} / \mathrm{h}$ in $30 \%$ ethanol-70\% saline, $n=8$ ) or control infusion (saline, $n=4$ and ethanol in saline, $n=4)$. The infusions were delivered at $0.57 \mathrm{~mL} / \mathrm{h}$ beginning at $1800 \mathrm{~h}$, $6 \mathrm{~h}$ before " 0 " time, to allow for the dead space of the fetal venous catheter $(3.1 \mathrm{~mL})$. The dose of RU26752 $(20 \mathrm{mg} / 12 \mathrm{~h})$ was chosen as 20 -fold excess relative to cortisol, assuming maternal cortisol production of $1 \mathrm{mg} / \mathrm{kg} / \mathrm{d}$ and $1.4 \%$ maternal-to-fetal transfer (7). This dose is 4 - to 5-fold the dose of spironolactone used to block infused aldosterone in the fetus (17); spironolactone and RU26752 have similar inhibitory concentrations at MR (18). The timing was chosen based on preliminary studies and an expected half-life of $1-2 \mathrm{~h}$ of the drug. The total dose of ethanol infused was $2 \mathrm{~mL} / 12 \mathrm{~h}$. Fetal ACTH does not increase after infusion of $0.75 \mathrm{~g} / \mathrm{kg} / \mathrm{h}$ ethanol (19), and 0.5 $\mathrm{g} / \mathrm{kg} / 8 \mathrm{~h}$ ethanol was shown not to alter blood gases in the fetus (20). Infusion of ethanol in our study produced similar responses as infusion of saline alone.

After $8 \mathrm{~h}$ of infusion, ewes were loaded into a metabolic cart; one end of the tracheal catheter was attached to a sterile reservoir to allow sampling of lung liquid volume. Lung liquid production from 10 to $12 \mathrm{~h}$ was determined by dye dilution using blue dextran as previously described $(15,16)$. Dye dilution was calculated in samples $(0.5 \mathrm{~mL})$ collected at 10 -min intervals; additional fluid $(0.3 \mathrm{~mL})$ was collected each $30 \mathrm{~min}$ for measurement of electrolyte concentrations. The initial volume of lung fluid was determined from the dilution of the dye in the $10 \mathrm{~h}$ sample; lung liquid volume at each time was calculated from the dye absorbance at $620 \mathrm{~nm}$ taking into account the volume of dye injected, dye concentration, and the sample volumes. The

\footnotetext{
Abbreviations: CRH, corticotropin releasing hormone; ENaC, epithelial sodium channel; GR, glucocorticoid receptor; HPA, hypothalamo-pituitaryadrenal; MR, mineralocorticoid receptor; PCV, packed cell volume; POMC, proopiomelanocortin; PVN, paraventricular nucleus; SGK, serum and glucocorticoid kinase
} 
rate of lung liquid production was calculated as the slope of the volume versus time relationship for each fetus.

Fetal blood pressure, amniotic pressure, and heart rate were measured from 9-12 h of infusion (Lab View; National Instruments, Austin, TX). Fetal arterial blood samples were collected every 30 min from 9 to $12 \mathrm{~h}(0.75 \mathrm{~mL})$ for measurement of fetal $\mathrm{PO}_{2}, \mathrm{PCO}_{2}, \mathrm{pH}$ (Radiometer ABL77; Copenhagen, Denmark), osmolality (Precision Instruments Inc, Natick, MA), and electrolytes (Roche 9180 analyzer). Packed cell volume (PCV) was also measured (International Equipment, Needham, MA). Blood $(5.5 \mathrm{~mL})$ for hormone analysis was collected at 9, 10, 11, and $12 \mathrm{~h}$ from the fetus (total volume of blood $27.5 \mathrm{~mL}$ over $3 \mathrm{~h}$ ) and at 10 and $12 \mathrm{~h}$ from the ewe (EDTA Vacutainer tubes; BD, Franklin Lakes, NJ); aliquots of plasma were frozen for subsequent analysis of hormone concentrations. Plasma ACTH was measured by RIA (16). Plasma cortisol was measured using ELISA (Oxford Biomedical Research Inc, Oxford, MI). Plasma aldosterone was measured by RIA (Diagnostic Products, Los Angeles, CA).

One fetus became severely hypoxic and died during the last hour of MR antagonist infusion; data from that fetus were excluded from the analysis. Data from one severely hypoxic fetus in the MR antagonist group and two fetuses in the control group (multiple $\mathrm{Po}_{2}<16 \mathrm{~mm} \mathrm{Hg}$ before infusion) were also excluded from analysis. In two fetuses, one per group, lung liquid did not properly mix with dye, and lung liquid production data were also excluded from analysis. Therefore, the sample sizes for lung liquid analysis are five per group, whereas the sample sizes for plasma hormone, plasma electrolytes, and blood gas data are six per group.

Gene expression after infusion of MR antagonist. Immediately after the $12 \mathrm{~h}$ sample, the ewe was killed (Virbac Inc, Fort Dodge, TX), and fetal tissues (hypothalamus, pituitary, and lung) were removed and frozen in liquid nitrogen. RNA was extracted from lung, a hemisected hypothalamus, and whole pituitary; real-time PCR was performed $(10,11)$. MR, GR, proopiomelanocortin (POMC), the MR target genes $(21,22)$, sodium-potassium ATPase $\alpha 1$ (Na,K ATPase $\alpha 1)$, the epithelial sodium channel $(\mathrm{ENaC} \alpha)$, and serum and glucocorticoid-regulated kinase1 (SGK1) mRNA were measured in lung ( $n=5 /$ group). MR, GR, corticotropin-releasing hormone (CRH), AVP, and $\beta$-actin mRNA were measured in hypothalamus, and MR, GR, POMC, and $\beta$-actin mRNA were measured in pituitary ( $n=6 /$ group). All samples for each gene, including no template control, were run on the same plate. The expression of each gene was quantified relative to the expression of $\beta$-actin in the same sample and analyzed by the $\Delta \mathrm{Ct}$ method. $\Delta \mathrm{Ct}$ values were used for statistical analysis. Fold changes were calculated as $2^{\Delta \Delta C t}$ using the mean value of the control group.

ENaC, Na,KATPase, and SGK protein in lung. The expression of the $\mathrm{ENaC} \alpha$ and $\mathrm{SGK} 1$ proteins was quantified in whole cell and membraneenriched fractions prepared from fetal lungs using previously described immunoblot techniques and validated antibodies (ENaC $\alpha, 3464,1: 100: \mathrm{Ab}-$ Cam, Cambridge, MA; Na,K ATPase, MA3-929 1:10,000: Affinity BioReagents, Golden, CO; SGK1, sc-15885, 1:1000: Santa Cruz Bioreagents, Santa Cruz, CA; $\beta$-actin, A-5441, 1:20000: Sigma Chemical Co.-Aldrich) (11). Single aliquots of each sample were run in gels containing samples from both groups; all blots for a given protein were run and developed simultaneously using the same reagents. The blots were analyzed with a Bio-Rad Chemi-Doc system and Quantity One software (Bio-Rad, Hercules, CA); the ENaC $\alpha$, Na,K ATPase $\alpha 1$ (100 $\mu \mathrm{g}$ protein/sample) and SGK1 (90 $\mu \mathrm{g}$ protein/sample) density results were expressed as the OD units normalized to the corresponding OD of the $\beta$-actin band on the same immunoblot.

Immunohistochemistry of MR and GR in fetal hypothalamus. Sections of fetal hypothalamus collected in a previous study from four control fetuses of 122-128 d were used to determine whether MR and GR colocalize in the fetal hypothalamus. Hypothalami were collected in $4 \%$ paraformaldehyde, embedded in paraffin, and sectioned at $5 \mu \mathrm{m}$. Sections were subjected to antigen retrieval (microwaving in sodium citrate buffer $0.1 \mathrm{M}$ ), blocked with blocking buffer (5\% milk, 5\% goat serum, $0.2 \%$ SDS in $0.05 \mathrm{M}$ Tris $\mathrm{pH} 7.6$, for $1 \mathrm{~h}$ ), and incubated with GR primary antibody (M20, sc-1002, 1:100; Santa Cruz Bioreagents) in blocking buffer for $1 \mathrm{~h}$, then with goat anti-rabbit IgG coupled to Alexa-Fluor 544 (1:500; Invitrogen, Carlsbad, CA) for $1 \mathrm{~h}$. Slides were reblocked and incubated with anti-MR primary antibody (M1-18 6G1, 1:40; Elise Gomez-Sanchez; Ref. 23) overnight at $4{ }^{\circ} \mathrm{C}$ in blocking buffer with $0.05 \%$ Tween 20 (Sigma Chemical Co. Aldrich), then with secondary antibody (goat anti-mouse IgG coupled to AlexaFluor 488; 1:500; Invitrogen). Sections treated with all reagents except primary antibodies were used as negative control; positive controls were fetal hippocampal sections from the same fetuses. Sections were viewed and photographed using an Olympus BX41 system microscope with DP-71 camera and DP-BSW Olympus imaging software (Olympus America Inc., Center Valley, PA).

Data analysis. Changes in plasma ACTH, cortisol, aldosterone, blood gases, PCV, plasma and lung fluid electrolytes, and lung liquid volume over time were analyzed by two-way ANOVA corrected for repeated measures over time. Differences in gene and protein expression, initial lung liquid volume at $10 \mathrm{~h}$, and lung fluid ratio of $\mathrm{Na}$ to $\mathrm{K}$ were analyzed by $t$ test. Differences in the rate of lung liquid production $(\mathrm{mL} / \mathrm{h})$ were analyzed by Mann-Whitney $U$ test as this variable was not normally distributed. The criteria for significance for all tests were $p<0.05$.

\section{RESULTS}

Effects on the hypothalamo-pituitary-adrenal axis. Treatment with an MR antagonist significantly increased ACTH and cortisol (Fig. 1). Plasma ACTH was significantly greater in MR antagonist-treated fetuses than in control fetuses at $12 \mathrm{~h}$. In addition, in the MR antagonist-treated fetuses, ACTH concentrations at $12 \mathrm{~h}$ were greater than in the same fetuses before treatment. In contrast, there was no significant increase in plasma ACTH in the control fetuses. Similarly, plasma cortisol concentrations at 11-12 $\mathrm{h}$ were greater in the MR antagonist-infused fetuses than in control fetuses, and cortisol increased significantly over time in the fetuses treated with MR antagonist, but not in control fetuses. There were no differences in plasma aldosterone concentrations in the fetuses treated with the MR blocker compared with the control fetuses (control fetuses: $137 \pm 33 \mathrm{pg} / \mathrm{mL}$ pretreatment and $191 \pm 34$ $\mathrm{pg} / \mathrm{mL}$ at $12 \mathrm{~h}$; MR antagonist-treated fetuses: $189 \pm 32$ $\mathrm{pg} / \mathrm{mL}$ pretreatment and $221 \pm 32 \mathrm{pg} / \mathrm{mL}$ at $12 \mathrm{~h}$ ).

Expression of CRH in the hypothalamus was not significantly changed by administration of the MR antagonist, nor was expression of POMC, MR or GR in the pituitary (Fig. 2). However, there was a significant decrease in GR and AVP mRNAs in the hypothalamus of MR antagonist-treated fetuses (Fig. 2). Immunofluorescence staining of hypothalamus showed coexpression of MR and GR in cells, these were primarily localized to the periventricular area of the paraventricular nucleus (PVN; Fig. 3).
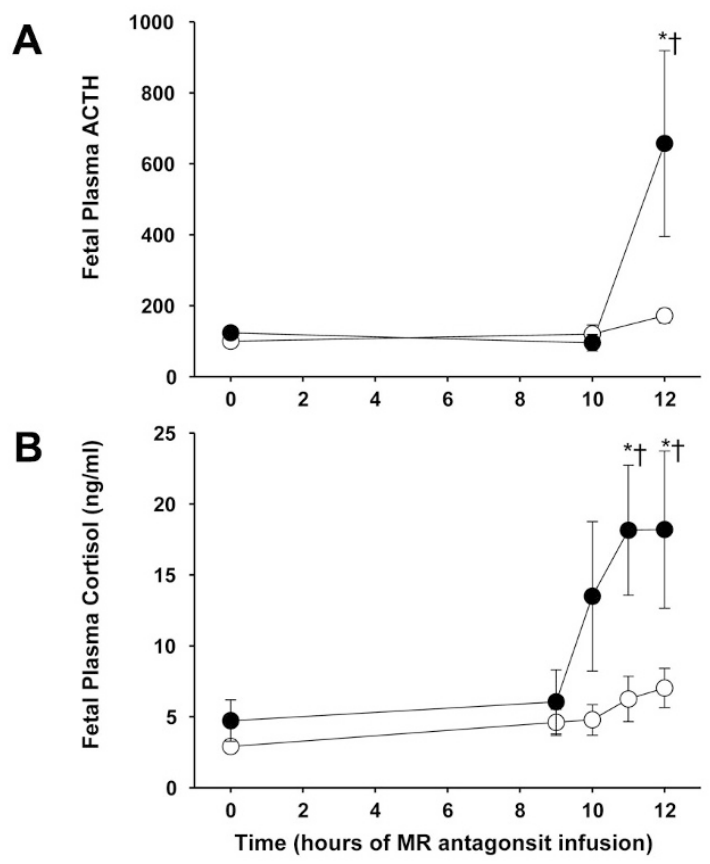

Figure 1. Plasma ACTH $(A)$ and cortisol $(B)$ concentrations in control fetuses $(\bigcirc)$ and fetuses infused with MR antagonist, RU 26752 (O). Data are shown as mean $\pm \mathrm{SEM}$; * indicates values in the treated fetuses greater than those in the control group at the same time; $\dagger$ indicates values different from $0 \mathrm{~h}$. 

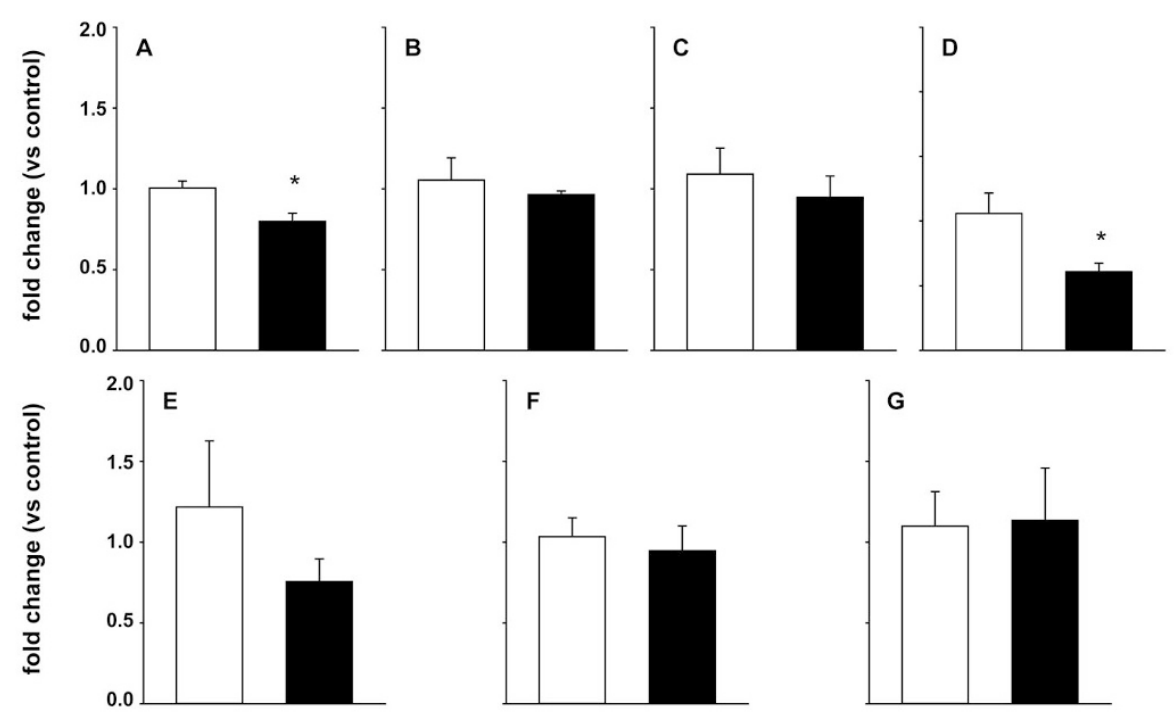

Figure 2. Gene expression in hypothalamus $(A-D)$ and pituitary $(E-G)$ in control fetuses $(\square)$ and fetuses infused with MR antagonist (ם). (A and $E) \mathrm{GR} ;(B$ and $F) \mathrm{MR} ;(C) \mathrm{CRH} ;(D) \mathrm{AVP}$; $(G)$ POMC; * indicates different from control. Data are mean fold changes \pm SEM relative to the mean in the control group.
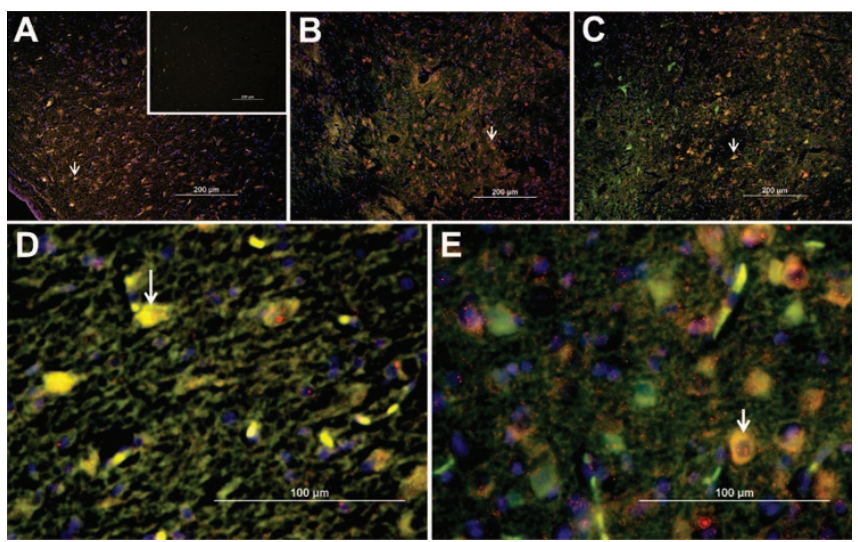

Figure 3. Localization of GR (red) and MR (green) in PVN $(A-D)$ and hippocampus of the fetus. Nuclei are stained with blue with DAPI. Examples of colocalization of MR and GR (yellow or orange) are indicated with white arrows. Inset in $(A)$ is from a control section with application of all reagents except the primary antibodies. Bars represent $200 \mu \mathrm{m}$ for $A-C$ and $100 \mu \mathrm{m}$ for $D$ and $E$.

Several factors related to fetal homeostasis were also changed in the MR antagonist-treated fetuses (Fig. 4). $\mathrm{PCO}_{2}$ was significantly increased, and $\mathrm{pH}$ was significantly decreased in fetuses after 11.5 and $12 \mathrm{~h}$ of MR antagonist infusion compared with control fetuses. PCV was significantly increased at 9-12 h of infusion of MR antagonist, although the MR antagonist did not significantly alter either fetal blood pressure or heart rate (blood pressure at $9-12 \mathrm{~h}$ in control: $43.7 \pm 2.6 \mathrm{~mm} \mathrm{Hg}$ compared with MR antagonist: $44.8 \pm 1.9$ $\mathrm{mm} \mathrm{Hg}$; heart rate at $9-12 \mathrm{~h}$ in control: $167.7 \pm 1.7 \mathrm{~min}^{-1}$ versus $\mathrm{MR}$ antagonist: $156.1 \pm 6.5 \mathrm{~min}^{-1}$ ). Infusion of the MR antagonist did not alter fetal plasma electrolytes or plasma $\mathrm{Na} / \mathrm{K}$ ratio.

Effects on fetal lung. Lung liquid production over time was not altered in fetuses infused with RU26752 (Fig. 1); the rate of lung liquid production (slope of the volume versus time relationship) was also not altered (control: $27.0 \pm 11.4 \mathrm{~mL} / \mathrm{h}$; MR antagonist: $16.8 \pm 4.5 \mathrm{~mL} / \mathrm{h})$. However, the electrolyte content of lung liquid was significantly altered by infusion of the MR antagonist (Fig. 5 and Table 1). The ratio of $\mathrm{Na}^{+}$to $\mathrm{K}^{+}$in lung liquid was significantly greater in the fetuses treated with MR antagonist. Lung liquid osmolality was not significantly different in MR antagonist-infused fetuses. There were no significant effects of MR antagonist on expression of any genes measured in fetal lung, including MR, GR, POMC, $\mathrm{ENaC} \alpha, \mathrm{Na}, \mathrm{K}$ ATPAse $\alpha 1$, or SGK1, nor were whole cell content of $\mathrm{ENaC} \alpha, \mathrm{Na}, \mathrm{K}$ ATPase $\alpha 1$, or SGK1 protein, or membrane content of $\mathrm{ENaC} \alpha$ proteins altered by MR antagonist infusion (Table 1).

\section{DISCUSSION}

The results demonstrate actions of endogenous corticosteroids at MRs in fetal sheep. Infusion of a MR antagonist increased plasma ACTH and cortisol, suggesting a role of MR in determining hypothalamo-pituitary-adrenal (HPA) activity in the fetus. Infusion of a MR antagonist did not alter basal lung liquid production, but did increase the $\mathrm{Na} / \mathrm{K}$ ratio in lung liquid, suggesting that corticosteroids play a role in the composition of lung liquid.

MR antagonists have been shown to increase ACTH concentrations in rats (24) and humans $(25,26)$, indicating that MR are involved in negative feedback control of ACTH. Presence of a similar negative feedback by MR in the fetus is consistent with the expression of MR in the ovine fetus in brain areas involved in regulation of the HPA, including the hippocampus, hypothalamus, and brainstem (10).

There was no change in either pituitary or pulmonary expression of POMC, nor were hypothalamic CRH or AVP mRNAs increased. However, we cannot rule out the possibility that small changes in expression in a discrete subgroup of cells were diluted in our analysis. It is also likely that the acute nature of the stimulus to ACTH increased hormone secretion without altering transcription. Although $6 \mathrm{~h}$ of hypoxemia stimulated CRH mRNA (27), more acute hypoxia stimulates ACTH without increasing CRH mRNA in hypothalamus (unpublished results, Wood laboratory). 

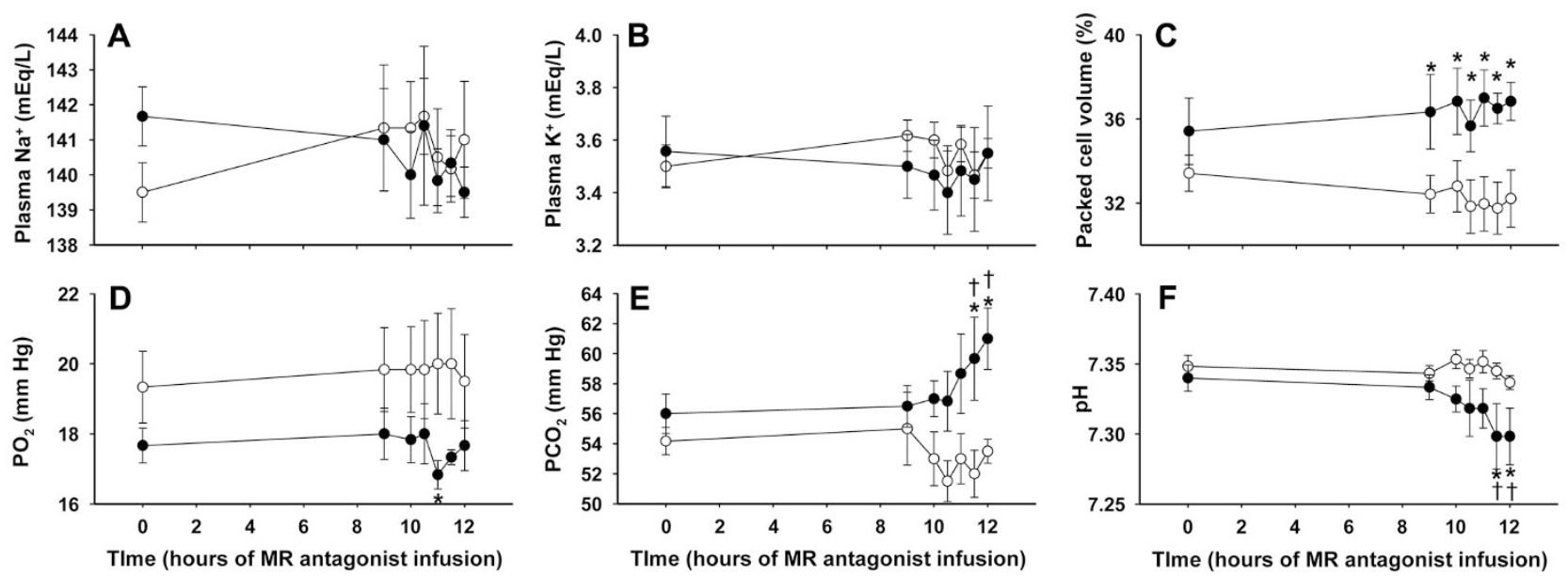

Figure 4. Plasma sodium $(A)$, potassium $(B), \mathrm{PCV}(C), \mathrm{Po}_{2}(D), \mathrm{PCO}_{2}(E)$, and $\mathrm{pH}(F)$ values in control fetuses $(\bigcirc)$ and fetuses infused with $\mathrm{MR}$ antagonist $(\bullet)$. Data as given in Fig. 1.
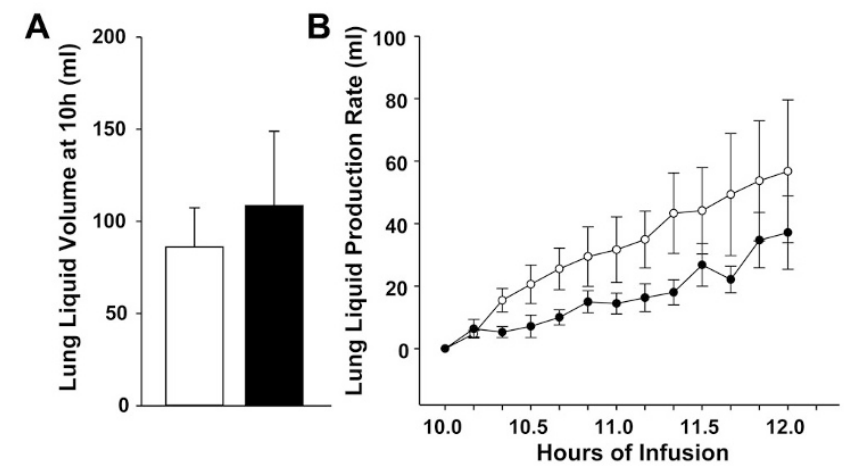

Figure 5. Lung liquid volume $(A)$ and lung liquid production $(B)$ in control fetuses $(\bigcirc)$ and fetuses infused with MR antagonist $(\bullet)$. Data as given in Fig. 1.

Table 1. Effects of MR antagonist treatment on the fetal lung

\begin{tabular}{|c|c|c|}
\hline & $\begin{array}{l}\text { Control } \\
\text { fetuses }\end{array}$ & $\begin{array}{l}\text { MR antagonist-treated } \\
\text { fetuses }\end{array}$ \\
\hline Lung liquid production $(\mathrm{mL} / 2 \mathrm{~h})$ & $27.0 \pm 11.4$ & $16.8 \pm 3.8$ \\
\hline Lung liquid $\mathrm{Na} / \mathrm{K}$ ratio & $30.2 \pm 1.7$ & $34.7 \pm 1.6^{*}$ \\
\hline \multicolumn{3}{|l|}{ Lung $\mathrm{ENaC} \alpha$ protein } \\
\hline Whole cell homogenate & $0.11 \pm 0.05$ & $0.07 \pm 0.03$ \\
\hline \multicolumn{3}{|l|}{ Lung $\mathrm{ENaC} \alpha$ protein } \\
\hline \multicolumn{2}{|l|}{ Lung $\mathrm{Na}, \mathrm{K}$ ATPase $\alpha 1$ protein } & $0.41 \pm 0.05$ \\
\hline Whole cell homogenate & $1.40 \pm 0.23$ & $1.33 \pm 0.17$ \\
\hline \multicolumn{3}{|l|}{ Lung Na,K ATPase $\alpha 1$ protein } \\
\hline Membrane fraction & $5.82 \pm 0.62$ & $5.09 \pm 0.47$ \\
\hline Lung SGK protein & $0.74 \pm 0.18$ & $0.87 \pm 0.09$ \\
\hline Lung $\mathrm{ENaC} \alpha$ mRNA & $1.08 \pm 0.17$ & $1.37 \pm 0.38$ \\
\hline Lung SGK1 mRNA & $1.06 \pm 0.16$ & $0.98 \pm 0.20$ \\
\hline Lung Na,K ATPase $\alpha 1$ mRNA & $1.12 \pm 0.25$ & $1.36 \pm 0.21$ \\
\hline Lung GR mRNA & $1.07 \pm 0.17$ & $0.88 \pm 0.22$ \\
\hline Lung POMC mRNA & $1.07 \pm 0.20$ & $1.60 \pm 1.00$ \\
\hline
\end{tabular}

Data are expressed as mean \pm SEM. Values for protein are expressed as optical density relative to that of $\beta$-actin. Gene expression is expressed as fold changes relative to the mean for the control fetuses.

* Value different than control fetuses.

GR expression in the hypothalamus was decreased in the fetuses after MR antagonist treatment, suggesting the possibility that increased ACTH could result from decreased feed- back at GR and MR. We found appreciable MR expression in the late gestation ovine fetal hypothalamus and MR and GR protein coexpressed within parts of the PVN; there is also colocalization of MR and GR in parvocellular neurons of the adult rat PVN (28). It is known that chronic increases in cortisol cause down-regulation of GR; however, GR downregulation has generally been shown to occur with chronic and sustained high levels of cortisol. The modest, acute changes in cortisol in the current studies would not be expected to alter GR expression; physiologic increases in cortisol do not seem to alter pituitary GR expression in the late gestation fetal sheep (29), and there is no decrease in hypothalamic GR expression at term (10). The unexpected decrease in GR may contribute to decreased feedback and increase HPA activity.

Our data also suggest that the MR blockade increased stimuli of ACTH. Both fetal PCV and fetal $\mathrm{PCO}_{2}$ significantly increased and $\mathrm{pH}$ decreased after $10-12 \mathrm{~h}$ of MR antagonist infusion. Acidemia and hypercapnia stimulate ACTH secretion in late gestation fetuses, although the magnitude of the changes in $\mathrm{PCO}_{2}$ and $\mathrm{pH}$ which alters $\mathrm{ACTH}$ is greater than the change in this study $(30,31)$. The changes in blood gases are also reminiscent of the changes during a progressive hemorrhage in late gestation fetal sheep (32). However, in contrast to progressive hemorrhage, the increase in ACTH occurs with relatively modest blood withdrawal ( $<10 \%$ of blood volume), without changes in blood pressure or heart rate. Using the PCV values to calculate changes in blood volume (33) and assuming an initial blood volume of $110-160 \mathrm{~mL} / \mathrm{kg}(16,33)$, we calculated significant differences in the change in blood volume in the control versus MR blocker-treated fetuses at $11 \mathrm{~h}(\Delta \mathrm{vol}$ of $+8-10 \mathrm{~mL} / \mathrm{kg}$ in control versus -3 to -5 $\mathrm{mL} / \mathrm{kg}$ after MR blocker). Although actions via MR in the fetal cardiovascular system have not been characterized, our data suggest that there may be changes in placental blood flow in the fetus during MR blockade, which result in an exaggerated hypercapnic response to modest blood withdrawal. MR are expressed in fetal brainstem (10), suggesting that MR blockade could alter responses to volume loss. If this is the case, then the increase in ACTH and cortisol may occur 
secondary to changes in blood flow and/or regulation of fluid balance, rather than simply by diminution of cortisol feedback. We cannot distinguish the relative importance of these effects in these studies.

Plasma aldosterone concentration did not change in fetal plasma during infusion of MR antagonist. However, plasma aldosterone concentration is not an index of MR blockade; MR do not directly alter renin or angiotensin secretion, and even infusion of a high dose of aldosterone does not alter plasma sodium in the fetus (34). In the fetus, plasma renin and angiotensin levels are high, but the fetal adrenal is relatively unresponsive to increases in angiotensin (35).

We found that AVP expression was decreased in the hypothalamus after administration of the MR antagonist. Increased cortisol levels suppress plasma AVP (36). In fetal sheep, cortisol decreased AVP mRNA in the parvocellular, although not the magnocellular, PVN (37). The reduction in AVP expression may therefore be secondary to the increased cortisol concentrations at $10-12 \mathrm{~h}$.

Our results suggest that MR effects in the fetal lung are relatively minor compared with the GR-mediated effects at term (38). The endogenous levels of cortisol in the 120-130 d fetus may not be sufficient to activate gene transcription or MR may not regulate these genes in the fetal lung. In the late gestation fetus, MR-mediated actions have been demonstrated $(17,34,39)$. In the postnatal kidney, effects of aldosterone are thought to be mediated by induction of $\mathrm{SGK}, \mathrm{ENaC}$, and $\mathrm{Na}, \mathrm{K}$ ATPase $(21,40)$. However, the mechanism of MR action in the lung may differ from that in the kidney, as aldosterone does not seem to affect SGK in the adult lung (22). MR and GR activate gene transcription through glucocorticoid response elements, which have been identified in the $\mathrm{ENaC} \alpha$ promoter (41). Synthetic glucocorticoids cause a robust induction of $\mathrm{ENaC}$ and $\mathrm{Na}, \mathrm{K}$ ATPase (42-44). However, for other genes, cortisol binding at MR induces less transcriptional activation than does aldosterone binding to MR or cortisol binding to GR (45), consistent with an absence of corticosteroid effect on "classical" MR-induced genes in fetal lung. The effect on $\mathrm{Na} / \mathrm{K}$ ratio in lung liquid suggests the possibility of a nongenomic MR effect on sodium conductance in the fetal lung. Absence of MR in knockout mice results in decreased sodium conductance without decreasing $\mathrm{ENaC}$ expression (46). Our results support a physiologic role of MR in altering composition of the fluid secreted as lung liquid without a significant effect on $\mathrm{ENaC}$ transcription.

Our results demonstrate that then normal low level of fetal corticosteroids act at MR in the ovine fetus and play a role in ACTH responses to mild stress. This effect limits the increase in fetal ACTH in the period before the fetal adrenal secretes appreciable quantities of cortisol. The results also suggest that MR play a role in fluid balance and lung liquid composition in fetal life. The fetal HPA axis itself is stimulated by changes in fluid homeostasis and changes in blood gases and contributes to fetal homeostatic responses to hypercapnia and to volume perturbations. Corticosteroid action at MR, therefore, is likely to be an important component of the endocrine control of fluid balance and the normal preterm suppression of ACTH.

\section{REFERENCES}

1. Liggins GC 1976 Adrenocortical-related maturational events in the fetus. Am J Obstet Gynecol 126:931-941

2. Jobe AH, Polk DH, Ervin MG, Padbury JF, Rebello CM, Ikegami M 1996 Preterm betamethasone treatment of fetal sheep: outcome after term delivery. J Soc Gynecol Investig 3:250-258

3. Ballard PL, Ertsey R, Gonzales LW, Gonzales J 1996 Transcriptional regulation of human pulmonary surfactant proteins SP-B and SP-C by glucocorticoids. Am J Respir Cell Mol Biol 14:599-607

4. Trahair JF, Perry RA, Silver M, Robinson PM 1987 Studies on the maturation of the small intestine in the fetal sheep. II. The effects of exogenous cortisol. Q J Exp Physiol 72:71-79

5. Dodic M, Wintour EM, Whitworth JA, Coghlan JP 1999 Effect of steroid hormones on blood pressure. Clin Exp Pharmacol Physiol 26:550-552

6. Fowden AL, Coulson RL, Silver M 1990 Endocrine regulation of tissue glucose-6phoshatase activity in the fetal sheep during late gestation. Endocrinology 126:28232830

7. Hennessy DP, Coghlan JP, Hardy KJ, Scoggins BA, Wintour EM 1982 The origin of cortisol in the blood of fetal sheep. J Endocrinol 95:71-79

8. Pepe GJ, Albrecht ED 1985 Transplacental corticosteroid metabolism during baboon pregnancy. In: Pepe GJ, Albrecht ED (eds) Perinatal Endocrinology. Perinatology Press, Ithaca, p 201

9. Richards EM, Hua Y, Keller-Wood M 2003 Pharmacology and physiology of ovine corticosteroid receptors. Neuroendocrinology 77:2-14

10. Keller-Wood M, Powers MJ, Gersting JA, Ali N, Wood CE 2006 Genomic analysis of neuroendocrine development of fetal brain-pituitary-adrenal axis in late gestation. Physiol Genomics 24:218-224

11. Keller-Wood M, von Reitzenstein M, McCartney J 2009 Is the fetal lung a mineralocorticoid receptor target organ? Induction of cortisol-regulated genes in the ovine fetal lung, kidney and small intestine. Neonatology 95:47-60

12. Condon J, Gosden C, Gardener D, Nickson P, Hewison M, Howie AJ, Stewart PM 1998 Expression of type 21 beta-hydroxysteroid dehydrogenase and corticosteroid hormone receptors in early human fetal life. J Clin Endocrinol Metab 83:4490-4497

13. Kim EK, Wood CE, Keller-Wood M 1995 Characterization of 11 betahydroxysteroid dehydrogenase activity in fetal and adult ovine tissues. Reprod Fertil Dev 7:377-383

14. Reini SA, Dutta G, Wood CE, Keller-Wood M 2008 Cardiac corticosteroid receptors mediate the enlargement of the ovine fetal heart induced by chronic increases in maternal cortisol. J Endocrinol 198:419-427

15. Davis TA, Gause G, Perks AM, Cassin S 1992 Effects of intravenous saline infusion on fetal ovine lung liquid secretion. Am J Physiol 262:R1117-R1120

16. Jensen E, Wood CE, Keller-Wood M 2003 Alterations in maternal corticosteroid levels influence fetal urine and lung liquid production. J Soc Gynecol Investig 10:480-489

17. Kairaitis K, Lumbers ER 1990 The influence of endogenous mineralocorticoids on the composition of fetal urine. J Dev Physiol 13:347-351

18. Fagart J, Seguin C, Pinon GM, Rafestin-Oblin ME 2005 The Met852 residue is a key organizer of the ligand-binding cavity of the human mineralocorticoid receptor. Mol Pharmacol 67:1714-1722

19. Cudd TA, Chen WJ, West JR 2001 Fetal and maternal sheep hypothalamus pituitary adrenal axis responses to chronic binge ethanol exposure during the third trimester equivalent. Alcohol Clin Exp Res 25:1065-1071

20. Smith GN, Brien JF, Carmichael L, Clarke DW, Patrick J 1989 Effect of acute, multiple-dose ethanol on maternal and fetal blood gases and acid-base balance in the near-term pregnant ewe. Can J Physiol Pharmacol 67:686-688

21. Pearce D, Verrey F, Chen SY, Mastroberardino L, Meijer OC, Wang J, Bhargava A 2000 Role of SGK in mineralocorticoid-regulated sodium transport. Kidney Int 57:1283-1289

22. Shigaev A, Asher C, Latter H, Garty H, Reuveny E 2000 Regulation of sgk by aldosterone and its effects on the epithelial $\mathrm{Na}(+)$ channel. Am J Physiol Renal Physiol 278:F613-F619

23. Gomez-Sanchez CE, de Rodriguez AF, Romero DG, Estess J, Warden MP, GomezSanchez MT, Gomez-Sanchez EP 2006 Development of a panel of monoclonal antibodies against the mineralocorticoid receptor. Endocrinology 147:1343-1348

24. Bradbury MJ, Akana SF, Dallman MF 1994 Roles of type I and II corticosteroid receptors in regulation of basal activity in the hypothalamo-pituitary-adrenal axis during the diurnal trough and the peak: evidence for a nonadditive effect of combined receptor occupation. Endocrinology 134:1286-1296

25. Young EA, Lopez JF, Murphy-Weinberg V, Watson SJ, Akil H 1998 The role of mineralocorticoid receptors in hypothalamic-pituitary-adrenal axis regulation in humans. J Clin Endocrinol Metab 83:3339-3345

26. Arvat E, Maccagno B, Giordano R, Pellegrino M, Broglio F, Gianotti L, Maccario M, Camanni F, Ghigo E 2001 Mineralocorticoid receptor blockade by canrenoate increases both spontaneous and stimulated adrenal function in humans. J Clin Endocrinol Metab 86:3176-3181

27. Matthews SG, Challis JR 1995 Regulation of CRH and AVP mRNA in the developing ovine hypothalamus: effects of stress and glucocorticoids. Am J Physiol 268:E1096-E1107

28. Han F, Ozawa H, Matsuda K, Nishi M, Kawata M 2005 Colocalization of mineralocorticoid receptor and glucocorticoid receptor in the hippocampus and hypothalamus. Neurosci Res 51:371-381

29. Green LR, Kawagoe Y, Fraser M, Challis JR, Richardson BS 2000 Activation of the hypothalamic-pituitary-adrenal axis with repetitive umbilical cord occlusion in the preterm ovine fetus. J Soc Gynecol Investig 7:224-232 
30. Wood CE, Chen H-G 1989 Acidemia stimulates ACTH, vasopressin, and heart rate responses in fetal sheep. Am J Physiol 257:R344-R349

31. Chen HG, Wood CE 1993 The adrenocorticotropic hormone and arginine vasopressin responses to hypercapnia in fetal and maternal sheep. Am J Physiol 264:R324$\mathrm{R} 330$

32. Wood CE, Chen H-G, Bell ME 1989 Role of vagosympathetic fibers in the control of adrenocorticotropic hormone, vasopressin, and renin responses to hemorrhage in fetal sheep. Circ Res 64:515-523

33. Brace RA 1983 Fetal blood volume responses to acute fetal hemorrhage. Circ Res 52:730-734

34. Siegel SR, Oakes G, Palmer S 1981 Transplacental transfer of aldosterone and its effects on renal function in the fetal lamb. Pediatr Res 15:163-165

35. Robillard JE, Nakamura KT, Lawton WJ 1985 Effects of aldosterone on urinary kallikrein and sodium excretion during fetal life. Pediatr Res 19:1048-1052

36. Papanek PE, Raff K 1994 Physiological increses in cortisol inhibit basal vasopressin release in conscious dogs. Am J Physiol 266:R1744-R1751

37. Unno N, Wu WX, Ding XY, Li C, Hing WK, Nathanielsz PW 1998 The effects of fetal adrenalectomy at 110 days gestational age on AVP and CRH mRNA expression in the hypothalamic paraventricular nucleus of the ovine fetus. Brain Res Dev Brain Res 106:119-128

38. Jesse NM, McCartney J, Feng X, Richards EM, Wood CE, Keller-Wood M 2009 Expression of ENaC subunits, chloride channels, and aquaporins in ovine fetal lung: ontogeny of expression and effects of altered fetal cortisol concentrations. Am J Physiol Regul Integr Comp Physiol 297:R453-R461
39. Robillard JE, Ramberg E, Sessions C, Consamus B, Van Orden D, Weismann D, Smith FG Jr 1980 Role of aldosterone on renal sodium and potassium excretion during fetal life and newborn period. Dev Pharmacol Ther 1:201-216

40. Chen SY, Bhargava A, Mastroberardino L, Meijer OC, Wang J, Buse P, Firestone GL, Verrey F, Pearce D 1999 Epithelial sodium channel regulated by aldosteroneinduced protein sgk. Proc Natl Acad Sci U S A 96:2514-2519

41. Sayegh R, Auerbach SD, Li X, Loftus RW, Husted RF, Stokes JB, Thomas CP 1999 Glucocorticoid induction of epithelial sodium channel expression in lung and renal epithelia occurs via trans-activation of a hormone response element in the $5^{\prime}$ flanking region of the human epithelial sodium channel alpha subunit gene. J Biol Chem 274:12431-12437

42. Nakamura K, Stokes JB, McCray PB Jr 2002 Endogenous and exogenous glucocorticoid regulation of ENaC mRNA expression in developing kidney and lung. Am J Physiol Cell Physiol 283:C762-C772

43. Venkatesh VC, Katzberg HD 1997 Glucocorticoid regulation of epithelial sodium channel genes in human fetal lung. Am J Physiol 273:L227-L233

44. Itani OA, Auerbach SD, Husted RF, Volk KA, Ageloff S, Knepper MA, Stokes JB, Thomas CP 2002 Glucocorticoid-stimulated lung epithelial $\mathrm{Na}(+)$ transport is associated with regulated ENaC and SGK1 expression. Am J Physiol Lung Cell Mol Physiol 282:L631-L641

45. Farman N, Rafestin-Oblin ME 2001 Multiple aspects of mineralocorticoid selectivity. Am J Physiol Renal Physiol 280:F181-F192

46. Berger S, Bleich M, Schmid W, Greger R, Schutz G 2000 Mineralocorticoid receptor knockout mice: lessons on Na+ metabolism. Kidney Int 57:1295-1298 